\title{
MOISTURE CONTENT IMPACT ON MECHANICAL PROPERTIES OF SELECTED COHESIVE SOILS FROM THE WIELKOPOLSKIE VOIVODESHIP SOUTHERN PART
}

\author{
PIOTR PEZOWICZ, KRYSTYNA CHOMA-MORYL
}

\begin{abstract}
University of Wrocław, Department of Applied Hydrogeology, Institute of Geological Sciences,
\end{abstract}
Wrocław, Poland, e-mail: zhs@ing.uni.wroc.pl

\begin{abstract}
Results of investigations of shearing resistance and compressibility of fine-grained cohesive soil from the southern part of the wielkopolskie voivodeship in relation to the increasing moisture content are presented. The analysis of two series of samples, using soil paste for the consistency index of 0.9 and $0.4-0.3$ was carried out. The results imply that the increasing moisture content causes a decrease in the angle of shearing resistance and cohesion and is also reflected in the higher compressibility of the soil. It was observed that regardless of the soil consistency, the angle of shearing resistance decreases and the cohesion value and the oedometric modulus of primary (consolidation) and secondary compressibility grows with the increase in the clay fraction.
\end{abstract}

Key words: soil consistency, shearing resistance, compressibility

\section{INTRODUCTION}

Mechanical properties of soils, assessed chiefly on the basis of the shearing resistance and compressibility, depend on a number of factors implied by their origin, geological history and alterations in the hypergene zone. Fine-grained, soft soils contain clayey fraction, below $0.002 \mathrm{~mm}$, where highly hydrophilic clay minerals are concentrated. Those soils have a well-developed specific surface, on which significant quantities of bound water may retain. Along with the increasing water content in these soils, their consistency changes from stiff to soft (PN-EN ISO 14688-2:2006 [22]). The soil consistency has impact on the values of its shearing resistance and compressibility.

The paper concentrates on the assessment of values variation range of the shearing resistance angle and the oedometric compressibility modulus, where as a result of the soil moisture content increase, the soil having stiff consistency $\left(I_{C}=0.9\right)$ will have the soft consistency $\left(I_{C}=0.4-0.3\right)$.

The research was carried out on soil pastes in which the natural structural bonds controlled by the sediment origin were destroyed. This facilitated analysis of only selected factors. Such research model may provide an explanation as to the extent to which the change of consistency from stiff to soft would diminish the properties of soils as a building substrate. The results may also be used for the assessment of mechanical properties of soils used in earthen structures. The performance of research on soil pastes enabled the analysis solely of the moisture content impact on the shearing resistance and compressibility at a constant granulometric and mineralogical composition. Model research on soil pastes was presented, e.g., by Szczepański [25], Borowczak [3] and Dobak, Kowalczyk [8].

The cohesive soils in Poland are represented chiefly by the Poznań clays (Neogene) and glacial tills (Pleistocene). In the southern part of the Wielkopolskie Voivodeship, these sediments have been mined as a raw material for ceramic industry for many years. Sediments occur at shallow depths and in large quantities, therefore being easily accessible as a material which can be used as a liner for waste landfills, and to construct flood dykes or water reservoir dams. Insulation properties, such as water permeability or sorption properties, have been studied for many years. On the other hand, only sparse data on the mechanical properties of these sediments with regard to their application as waste landfill liner, flood dyke or water dam construction were published. In all of these facilities, the soil moisture content may increase an unexpected failure. Therefore, an assessment is necessary of the degree to which the transition of the soil to the soft consistency will diminish their shearing resistance and 
increase the compressibility. This is important both with regard to the waste landfill lining and hydroengineering structures, as to have adequate mechanical properties in addition to insulation properties.

\section{METHODS OF INVESTIGATION}

The research was carried out near the towns of Rawicz and Krotoszyn in the S part of the Wielkopolskie Voivodeship (Fig. 1).

The analysis of archival documentations, chiefly of the Detailed Geological Maps of Poland to the scale of 1: 50000 - the Krotoszyn sheet (Błaszczyk [2]) and the Rawicz sheet (Nowak [15]), the same sheets of the sozological maps, and also papers by Piwocki [19], Kasiński, Czapowski [12], the data from the Krotoszyn Town Office [31], as well as papers by Szymkowiak et al. [27] and Kajetańczyk et al. [11], enabled selection of a dozen locations of glacial tills from the Middle Poland glaciation and the Poznan clays. The Poznań clays are grey or yellow-grey in colour, moist and have stiff consistency, while the glacial tills of the Middle Poland glaciations are brown or brown-grey, also moist and of stiff consistency.

After a site visit and location accessibility the following three sites were selected for detailed research: Rozstępniewo, Sulmierzyce and Biadki (Fig. 1).

During field work 16 holes were drilled (with a hand-held drill) to a depth of 3 meters, on the area of a former clay pit. Four soil samples were collected in Biadki (samples B1-B4), the same number in Rozstępniewo (samples R1-R2), whereas eight samples were collected in Sulmierzyce (samples S1-S8). The macroscopic observation allowed us to determine the name and the consistency of soil, moisture content and colour, and the calcium carbonate content. The investigations were carried out in accordance with two standards: PN-EN ISO 14688-1 [21] and PN-EN ISO
14688-2 [22]. The soil samples with the disturbed structure, natural moisture content and natural gradation were placed in tight bags and transported to the laboratory.

The laboratory tests were performed at the Engineering Geology Laboratory of the Institute of Geological Sciences at Wrocław University. Investigations of the physical properties included the natural moisture content measurement, the bulk density of soil, the plasticity limit determination with the rolling method and the liquid limit determination using the Casagrande method. The porosity and the void ratio has been calculated, too. The investigations were carried out on the basis of the standard PN-EN ISO 14688-2 [22] and PN-EN 1997-2 [23]. The granulometric content was determined using the pipette analysis after Myślińska [14] (substituting boiling of the mixture with agitation on the magnetic agitator). The angle of shearing resistance, cohesion and the oedometric modulus of compressibility were analysed in two series, using soil pastes.

The first series of tests, which involved analysis of soil with the natural moisture content, rendered the consistency index values $I_{C}=0.9$. In the second series, the paste moisture content was increased to reach the soft consistency, with the consistency index $I_{C}=$ $0.4-0.3$. Moistened samples were used to prepare soil pastes, which were then compacted upon reaching (in the air dry conditions) the assumed moisture content. Each sample was compacted in tightly shielded rings of $15 \mathrm{~cm}$ in diameter under a load of $200 \mathrm{kPa}$ until the volumetric density of in-situ soils was reached. The investigations carried out at such volumetric densities shall enable us to relate - with a certain approximation - the results to soils that form the building substrate. Moulds for shear test box and oedometer investigations were cut out from soils prepared in this way. During these investigations, the soils were not saturated with water.

The shear strength of soil was measured in the direct shearing apparatus Matest S277-02. The tests

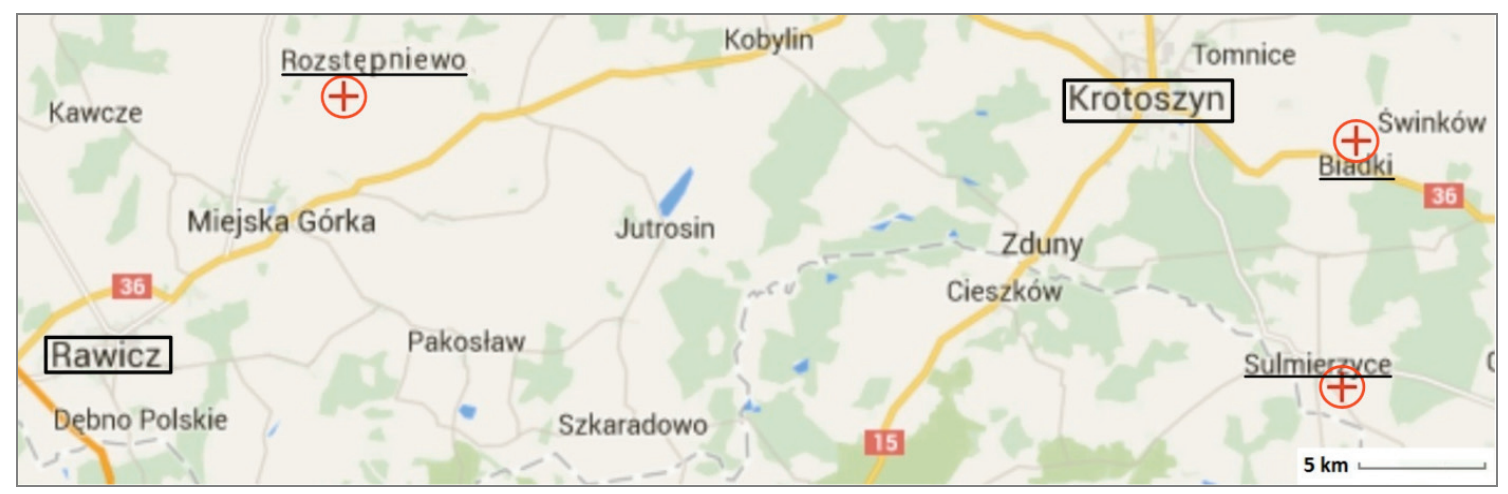

Fig. 1. Study area with the location of the sampling soils $(+-$ location of the sampling soils) 
were carried out with the Q (quick) method - unconsolidated and undrained soil was subjected to shearing. The shearing rate was set at $0.1 \mathrm{~mm} / \mathrm{min}$. Each soil sample was tested at the load equal to 100,150 and $200 \mathrm{kPa}$.

The investigations were carried out in line with the Coulomb-Mohr hypothesis. Upon testing of each mould under a given load, the apparatus generated a graph $\tau_{f}(\varepsilon)$, from which the maximum value for the first peak was read out - the moment of the sample shearing. When the complete set of $\tau_{f}$ values for each load was obtained, the Coulomb line was drawn, which in turn was used to determine the angle of shearing resistance and the cohesion (Fig. 2, Fig. 3,
Fig. 4). Each mould was sheared several times to eliminate errors, and therefore the maximum failure value was not determined. The deformation criterion was not determined due to the non-uniform state of sample deformation during the tests resulting from the specificity of the apparatus.

The compressibility was analysed in oedometers, while loading and unloading the samples until the settlement stability was reached and drawing the primary compressibility (consolidation), secondary compressibility and deformation curve. In accordance with the standard PKN-CEN ISO/TS 17892-5 [20], after each applied loading or unloading of the sample, the readout from the displacement sensors was made.

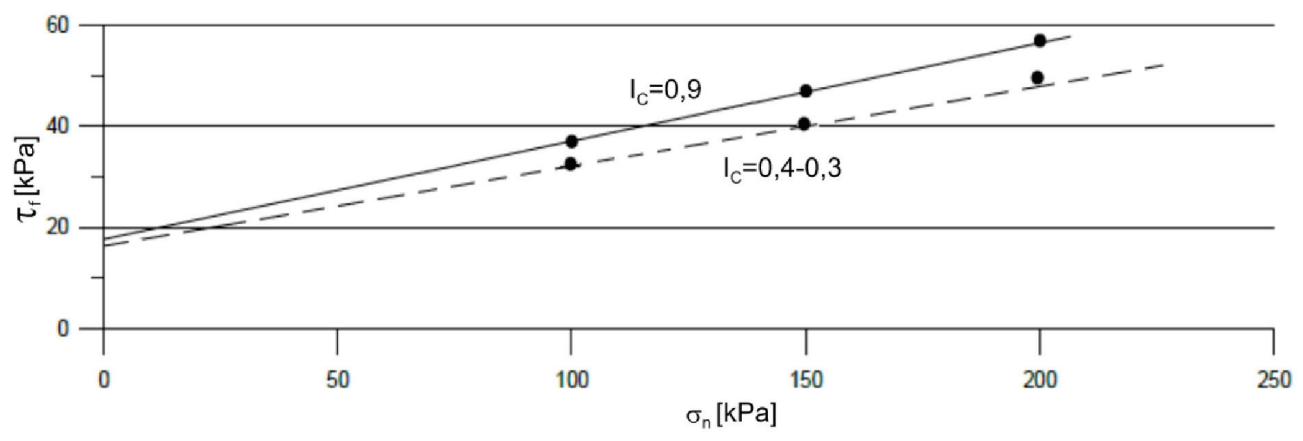

Fig. 2. Relation between the shear stress $\tau_{f}$ and the normal stress $\sigma_{n}$ according to the Coulomb-Mohr hypothesis for sample B1 being in the $\operatorname{stiff}\left(I_{C}=0.9\right)$ and the soft state $\left(I_{C}=0.4-0.3\right)$

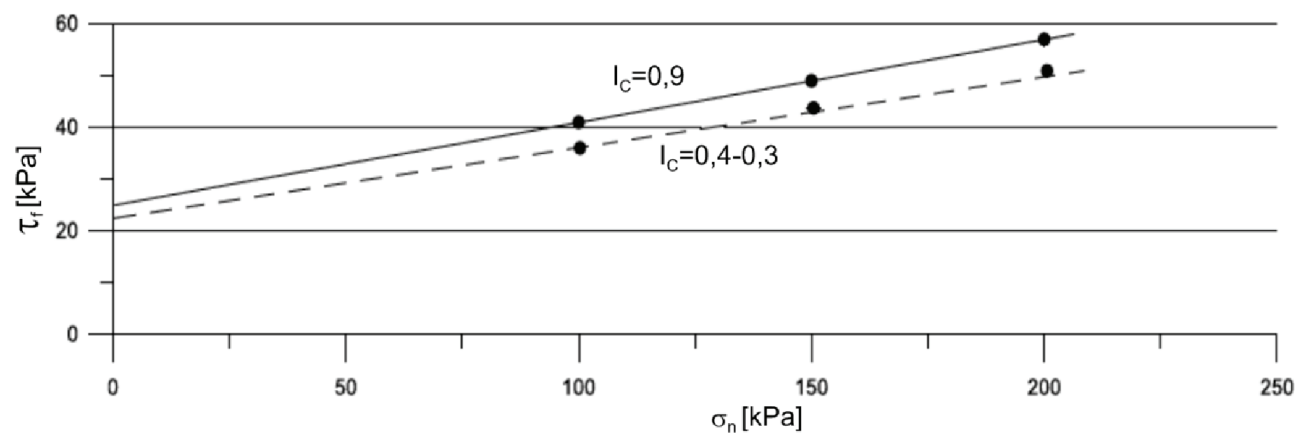

Fig. 3. Relation between the shear stress $\tau_{f}$ and the normal stress $\sigma_{n}$ according to the Coulomb-Mohr hypothesis for sample S2 being in the stiff $\left(I_{C}=0.9\right)$ and the soft state $\left(I_{C}=0.4-0.3\right)$

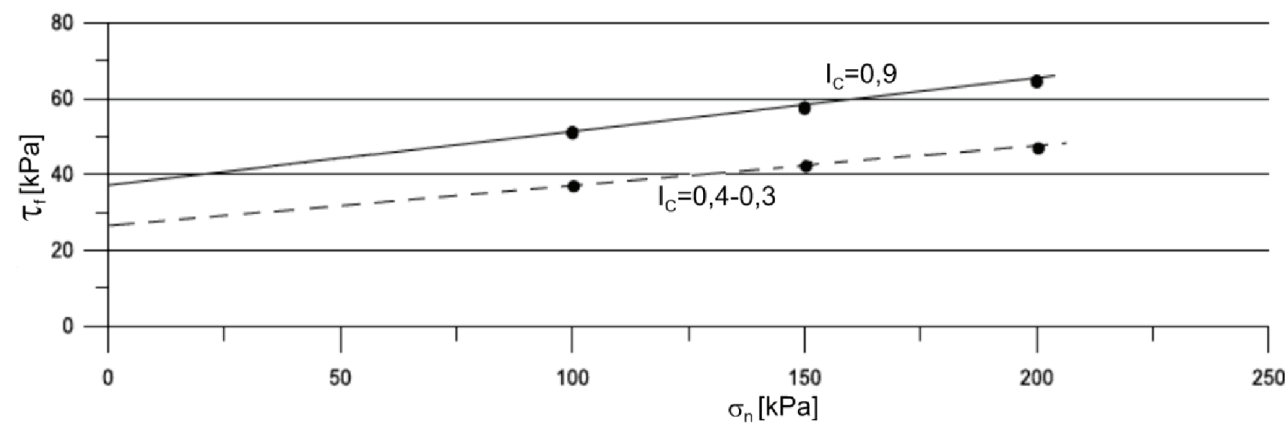

Fig. 4. Relation between the shear stress $\tau_{f}$ and the normal stress $\sigma_{n}$ according to the Coulomb-Mohr hypothesis for sample R1 being in the $\operatorname{stiff}\left(I_{C}=0.9\right)$ and the soft state $\left(I_{C}=0.4-0.3\right)$ 

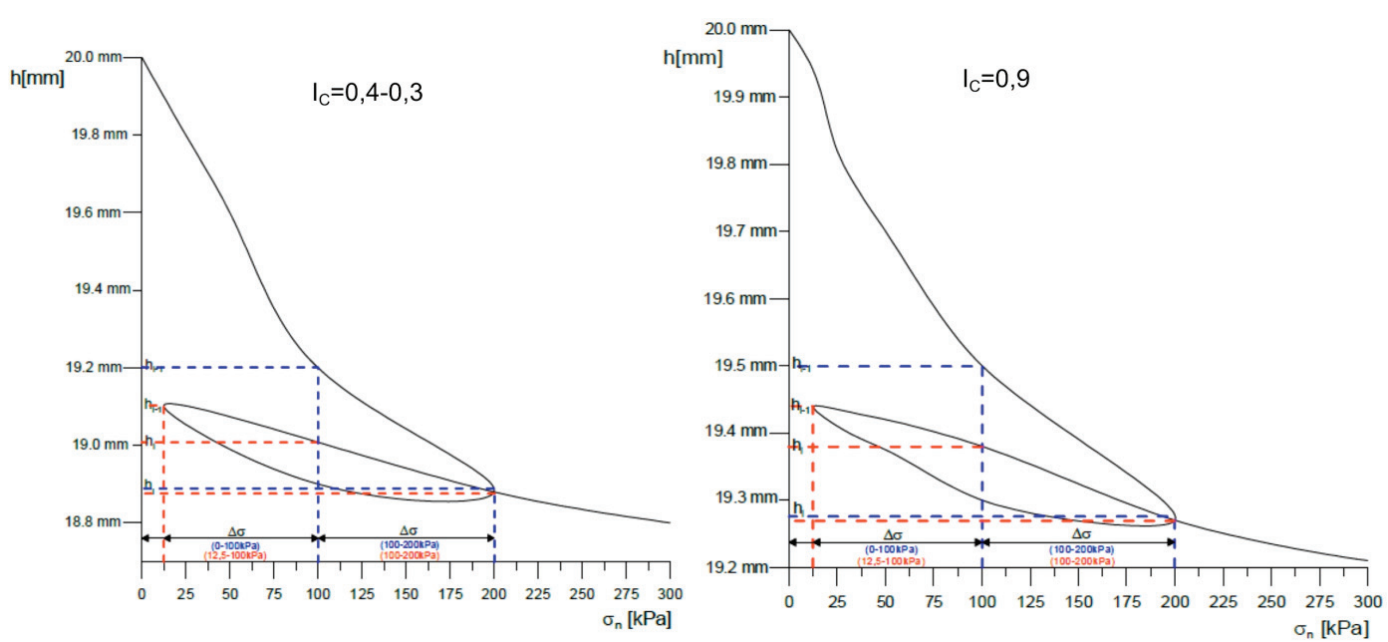

Fig. 5. Compressibility curve with calculation modules for sample B1 being in the stiff $\left(I_{C}=0.9\right)$ and the soft state $\left(I_{C}=0.4-0.3\right)$
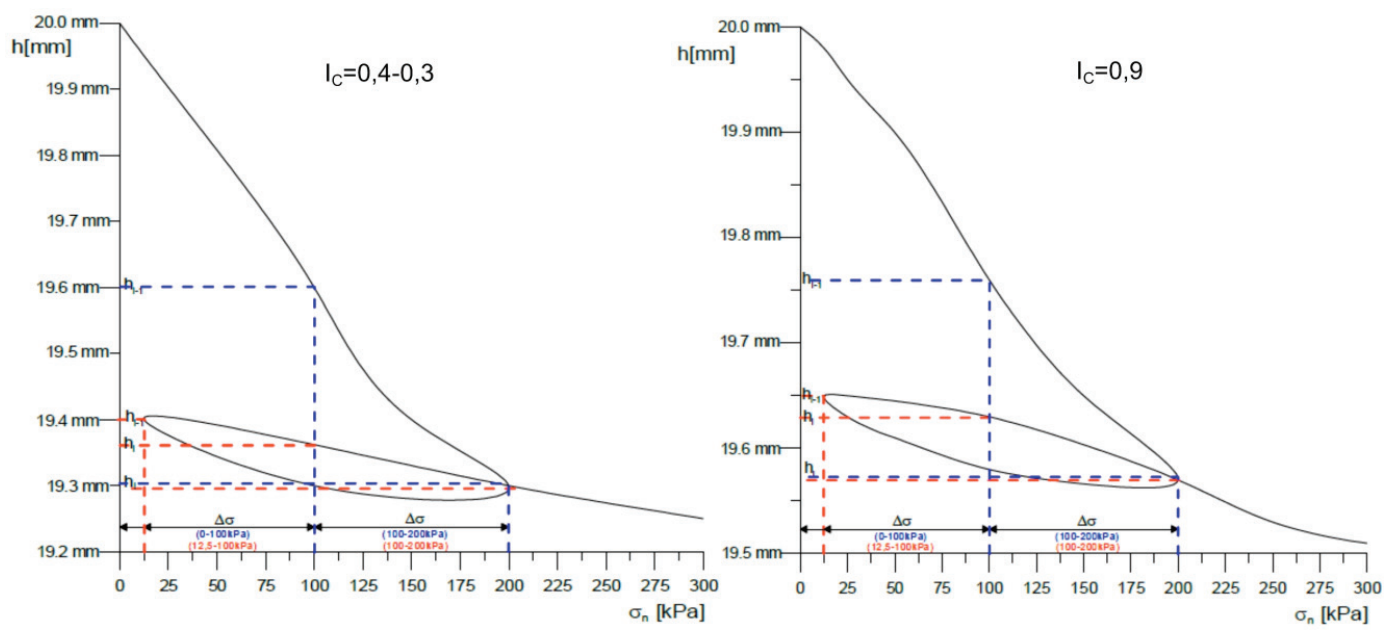

Fig. 6. Compressibility curve with calculation modules for sample R1 being in the stiff $\left(I_{C}=0.9\right)$ and the soft state $\left(I_{C}=0.4-0.3\right)$

After 24 hours necessary for the settlement stabilization, the following range of loads - two times higher or lower than the previous one - was applied. The consecutive loading applied to the samples amounted to $12.5,25,50,100$ and $200 \mathrm{kPa}$. Upon the test completion, oedometric modulus of primary compressibility for $0-100$ and $100-200 \mathrm{kPa}$ and oedometric modulus of secondary compressibility for $12.5-100$ and $100-200 \mathrm{kPa}$ were determined (Fig. 5., Fig. 6.).

\section{RESULTS AND DISCUSSION}

The granulometric composition determines the per cent concentration of individual fractions present in the soil in relation to the sample weight. It is one of the main factors influencing the shearing resistance
(Yuan et al. [35]) and the compressibility (Tiwari, Ajmera [28]) of soil.

The Poznan clays, collected from the Rozstępniewo (samples R1-R4) and Sulmierzyce (samples S1-S8 described as a clay) contain $0.1-0.2 \%$ of the gravel fraction, $3.2-42.1 \%$, of the sand fraction, $20.3-50.1 \%$ of the silt fraction, and $37.1-53.6 \%$ of the clay fraction (Table 1). The individual fraction concentrations are in accordance with the values presented in the papers by Choma-Moryl [5] and Duczmal-Czernikiewicz [9].

The tills from Biadki (samples B1-B4) described as a clay with sand and silt, representing the Middle Poland glaciation contain $2.0-4.6 \%$ of the gravel fraction, 42.8-47.0\%, of the sand fraction, 22.3$24.5 \%$ of the silt fraction, and $28.0-28.8 \%$ of the clay fraction (Table 1). All the soils were classified according to the standards mentioned PN-EN ISO 14688-1 [21] and PN-EN ISO 14688-2 [22]. 
Table 1. The test results for granulometric composition, natural moisture $\left(w_{n}\right)$, plastic limit (PL),

liquid limit $(\mathrm{LL})$, consistency index $\left(I_{C}\right)$, bulk density of soil $(\rho)$, porosity $(n)$, void ratio $(e)$

\begin{tabular}{|c|c|c|c|c|c|c|c|c|c|c|c|c|c|}
\hline \multirow{3}{*}{ No. } & \multirow{3}{*}{$\begin{array}{l}\text { Sample } \\
\text { symbol }\end{array}$} & \multicolumn{4}{|c|}{ Fraction [\%] } & \multirow{3}{*}{$\begin{array}{c}\text { Soil } \\
\text { samples } \\
\text { (PN-EN } \\
\text { ISO 14688-2) }\end{array}$} & \multirow{3}{*}{$\begin{array}{c}\text { Moisture } \\
w_{n}\end{array}$} & \multirow{3}{*}{\begin{tabular}{|c} 
Plastic \\
limit \\
PL
\end{tabular}} & \multirow{3}{*}{$\begin{array}{c}\text { Liquid } \\
\text { limit } \\
\text { LL }\end{array}$} & \multirow{3}{*}{$\begin{array}{l}\text { Consis- } \\
\text { tency } \\
\text { index } \\
I_{c}\end{array}$} & \multirow{3}{*}{$\begin{array}{c}\begin{array}{c}\text { Bulk } \\
\text { density } \\
\text { of soil } \\
\rho\end{array} \\
{\left[\mathrm{g} / \mathrm{cm}^{3}\right]}\end{array}$} & \multirow{3}{*}{\begin{tabular}{|c|}
$\begin{array}{c}\text { Porosity } \\
n\end{array}$ \\
\\
\\
{$[\%]$}
\end{tabular}} & \multirow{3}{*}{$\begin{array}{c}\text { Void } \\
\text { ratio } \\
e\end{array}$} \\
\hline & & $\mathrm{Gr}$ & $\mathrm{Sa}$ & $\mathrm{Si}$ & $\mathrm{Cl}$ & & & & & & & & \\
\hline & & $>2 \mathrm{~mm}$ & $\begin{array}{c}2-0.063 \\
\mathrm{~mm}\end{array}$ & $\begin{array}{c}0.063 \\
-0.002 \\
\mathrm{~mm} \\
\end{array}$ & $\begin{array}{c}<0.002 \\
\mathrm{~mm}\end{array}$ & & & & & & & & \\
\hline 1 & R1 & - & 10.6 & 36 & 53.4 & $\mathrm{Cl}$ & 22.8 & 20.1 & 72.5 & 0.9 & 2 & 40.1 & 0.67 \\
\hline 2 & $\mathrm{R} 2$ & - & 8.3 & 38.1 & 53.6 & $\mathrm{Cl}$ & 23.2 & 19.9 & 83.6 & 0.9 & 2 & 40.1 & 0.67 \\
\hline 3 & R3 & - & 9.1 & 39 & 51.9 & $\mathrm{Cl}$ & 22.7 & 18.7 & 77.5 & 0.9 & 2.02 & 39.3 & 0.65 \\
\hline 4 & R4 & - & 10.1 & 37.9 & 52 & $\mathrm{Cl}$ & 23.4 & 20.2 & 70.4 & 0.9 & 2.01 & 39.7 & 0.66 \\
\hline 5 & S5 & 0.1 & 5.1 & 47.2 & 47.6 & $\mathrm{Cl}$ & 23.8 & 16.3 & 69.3 & 0.9 & 2.11 & 36.9 & 0.58 \\
\hline 6 & S6 & 0.2 & 3.2 & 49.7 & 46.9 & $\mathrm{Cl}$ & 21.4 & 17.4 & 77.2 & 0.9 & 2.09 & 36.5 & 0.57 \\
\hline 7 & S7 & 0.1 & 4.5 & 50.1 & 45.3 & $\mathrm{Cl}$ & 22.2 & 16.1 & 74.3 & 0.9 & 2.11 & 36.5 & 0.58 \\
\hline 8 & S8 & 0.1 & 6.2 & 49.5 & 44.2 & $\mathrm{Cl}$ & 23.5 & 16.5 & 71.2 & 0.9 & 2.1 & 37.3 & 0.59 \\
\hline 9 & S1 & - & 42.1 & 20.3 & 37.6 & $\mathrm{Cl}$ & 15.6 & 13.1 & 51 & 0.9 & 2.06 & 33.8 & 0.51 \\
\hline \begin{tabular}{|l|}
10 \\
\end{tabular} & S2 & 0.1 & 40.3 & 22.5 & 37.1 & $\mathrm{Cl}$ & 15.6 & 13.2 & 50.8 & 0.9 & 2.07 & 33.4 & 0.5 \\
\hline 11 & S3 & 0.1 & 40.7 & 21.3 & 37.9 & $\mathrm{Cl}$ & 15.4 & 12.8 & 49.6 & 0.9 & 2.07 & 33.3 & 0.5 \\
\hline 12 & S4 & - & 39.9 & 23 & 37.1 & $\mathrm{Cl}$ & 16 & 13.5 & 51.9 & 0.9 & 2.06 & 34 & 0.51 \\
\hline 13 & B1 & 4.6 & 42.8 & 24.5 & 28.1 & sasiCl & 12.5 & 10.6 & 37.4 & 0.9 & 2.13 & 29.9 & 0.43 \\
\hline 14 & B2 & 2 & 47 & 22.3 & 28.7 & sasiCl & 13.1 & 11.2 & 35.5 & 0.9 & 2.13 & 30.2 & 0.43 \\
\hline 15 & B3 & 3.3 & 43.7 & 24.2 & 28.8 & sasiCl & 12.8 & 10.1 & 32.9 & 0.9 & 2.12 & 30.1 & 0.43 \\
\hline 16 & B4 & 4.1 & 44.6 & 23.2 & 28 & sasiCl & 12.9 & 10 & 36.6 & 0.9 & 2.14 & 29.5 & 0.42 \\
\hline
\end{tabular}

The volumetric density and the porosity values of the soils studied vary only in a small range (Table 1). Porosity ranges were found between 40.1 and $29.5 \%$. The lowest values were obtained for clay loams, which is understandable considering the most diversified concentration of the individual fractions.

One of the major factors influencing the mechanical properties of soil is the water content (Valasti [32]). Determination of the natural moisture content and the moisture content of consistency limits was the basis for the assessment of mechanical properties variation in the Poznan clays and the glacial tills (clay with sand and silt from Biadki) in relation to the soil consistency. The natural moisture content in most samples was close to the moisture content of the plastic limit. This means that the samples were collected in the stiff consistency $\left(I_{C}=0.9\right)$. The liquid limit of the investigated soils revealed dependence on the clay fraction content. For the Rozstepniewo soils (samples R1-R4) and part of the soils from Sulmierzyce (samples S5-S8), containing over $40 \%$ of the clay fraction, its value ranges between 69.3 and $83.6 \%$. In the case of the other soils, characterized by the clay fraction content close to $30 \%$, the liquid limit is much lower: $32.9-51 \%$ (Table 1).

Clays sheared in the stiff consistency $\left(I_{C}=0.9\right)$ had the angle of shearing resistance from 7 to 9 degrees and cohesion between 24 and $40 \mathrm{kPa}$. Those sheared in the soft consistency $\left(I_{C}=0.4-0.3\right)$ had the angle of shearing resistance from 4 to 7 degrees and cohesion between 22 and $29 \mathrm{kPa}$. In the case of the clay with sand and silt, the angles of shearing resistance values were from 11 to 12 degrees and the cohesion values were between 18 and $19 \mathrm{kPa}$, when the test was carried out in the stiff consistency $\left(I_{C}=0.9\right)$. Shearing of clay with sand and silt in the soft consistency $\left(I_{C}=0.4-0.3\right)$ rendered values of the angle of shearing resistance from 7 to 8 degrees, and the values of cohesion between 16 and $17 \mathrm{kPa}$ (Table 2).

The results of investigations imply that the moisture content increase caused the decrease in the angle of shearing resistance and the cohesion values. The results are in compliance with those quoted by numerous authors, for example, Gana, Rahardio [10], Pisarczyk [18], as well as Chudy and Pawlak [6].

The greatest differences between the values of the angle of shearing resistance for the soils in the stiff and the soft consistency reached $3-4^{\circ}$. Those results were determined in the clays with sand and silt near Biadki. In the clays differences were within a range of $1-2^{\circ}$. One exception was sample R2, for which the value was found to be $4^{\circ}$ (Fig. 7). The greatest impact of the increasing moisture content on cohesion was observed in the Poznań clays from Rozstępniewo, in which the clay fraction was in the range between $51.9 \%$ and $53.4 \%$. Differences between cohesion values at the 
Table 2. The test results for angle of internal friction $(\varphi)$, cohesion $(c)$, for consistency index $I_{C}=0.9$ and $I_{C}=0.4-0.3$

\begin{tabular}{|c|c|c|c|c|c|c|c|c|c|c|c|}
\hline No. & $\begin{array}{c}\text { Sample } \\
\text { symbol }\end{array}$ & $\begin{array}{c}\text { Moisture } \\
w_{n}[\%] \\
\text { before } \\
\text { test) }\end{array}$ & $\begin{array}{c}\text { Moisture } \\
w[\%] \\
\text { (after test) }\end{array}$ & $\begin{array}{c}\text { Consis- } \\
\text { tency } \\
\text { index } I_{c}\end{array}$ & $\begin{array}{c}\text { Angle of } \\
\text { internal } \\
\text { friction } \varphi \\
{\left[{ }^{\circ}\right]}\end{array}$ & $\begin{array}{c}\text { Cohesion } \\
c[\mathrm{kPa}]\end{array}$ & $\begin{array}{c}\text { Moisture } \\
w^{\prime}\left[\begin{array}{c}\% \\
\text { (before } \\
\text { test) }\end{array}\right.\end{array}$ & $\begin{array}{c}\text { Moisture } \\
w^{\prime}[\%] \\
(\text { after test) }\end{array}$ & $\begin{array}{c}\text { Consis- } \\
\text { tency } \\
\text { index } I_{c}{ }^{\prime}\end{array}$ & $\begin{array}{c}\text { Angle of } \\
\text { internal } \\
\text { friction } \varphi \\
{\left[{ }^{\circ}\right]}\end{array}$ & $\begin{array}{c}\text { Cohesion } \\
c[\mathrm{kPa}]\end{array}$ \\
\hline 1 & R1 & 22.8 & 17.7 & 0.9 & 7 & 39 & 57.3 & 48.8 & 0.3 & 5 & 26 \\
\hline 2 & R2 & 23.2 & 18.6 & 0.9 & 8 & 39 & 62.7 & 52.1 & 0.3 & 4 & 28 \\
\hline 3 & R3 & 22.7 & 18.0 & 0.9 & 7 & 40 & 61.5 & 50.7 & 0.3 & 5 & 28 \\
\hline 4 & R4 & 23.4 & 19.9 & 0.9 & 7 & 39 & 52.7 & 44.8 & 0.4 & 5 & 29 \\
\hline 5 & S5 & 23.8 & 20.7 & 0.9 & 7 & 36 & 47.2 & 37.1 & 0.4 & 5 & 26 \\
\hline 6 & S6 & 21.4 & 18.4 & 0.9 & 8 & 33 & 51.3 & 43.5 & 0.4 & 7 & 29 \\
\hline 7 & S7 & 22.2 & 18.6 & 0.9 & 7 & 34 & 50.1 & 41.2 & 0.4 & 6 & 29 \\
\hline 8 & S8 & 23.5 & 18.9 & 0.9 & 7 & 36 & 47.9 & 38.9 & 0.4 & 5 & 27 \\
\hline 9 & S1 & 15.6 & 13.7 & 0.9 & 8 & 25 & 40.0 & 31.1 & 0.3 & 7 & 23 \\
\hline 10 & S2 & 15.6 & 13.9 & 0.9 & 9 & 25 & 41.1 & 30.9 & 0.3 & 7 & 22 \\
\hline 11 & S3 & 15.4 & 13.5 & 0.9 & 9 & 25 & 37.5 & 29.0 & 0.3 & 7 & 23 \\
\hline 12 & S4 & 16.0 & 14.2 & 0.9 & 9 & 24 & 38.2 & 29.3 & 0.4 & 7 & 22 \\
\hline 13 & B1 & 12.5 & 12.0 & 0.9 & 11 & 19 & 30.4 & 16.2 & 0.3 & 8 & 17 \\
\hline 14 & B2 & 13.1 & 12.8 & 0.9 & 11 & 18 & 27.5 & 19.1 & 0.3 & 8 & 17 \\
\hline 15 & B3 & 12.8 & 11.9 & 0.9 & 11 & 19 & 24.4 & 19.7 & 0.4 & 7 & 16 \\
\hline 16 & B4 & 12.9 & 11.4 & 0.9 & 12 & 19 & 26.5 & 20.9 & 0.4 & 8 & 17 \\
\hline
\end{tabular}

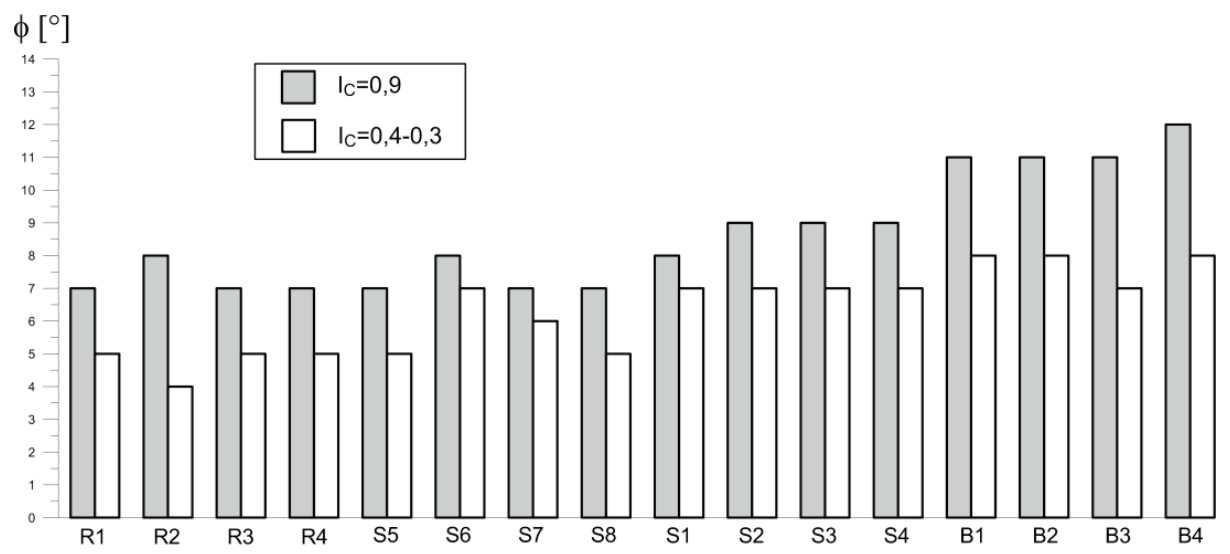

Fig. 7. Comparison of the internal friction angle for consistency index $I_{C}=0.9$ and $I_{C}=0.4-0.3$

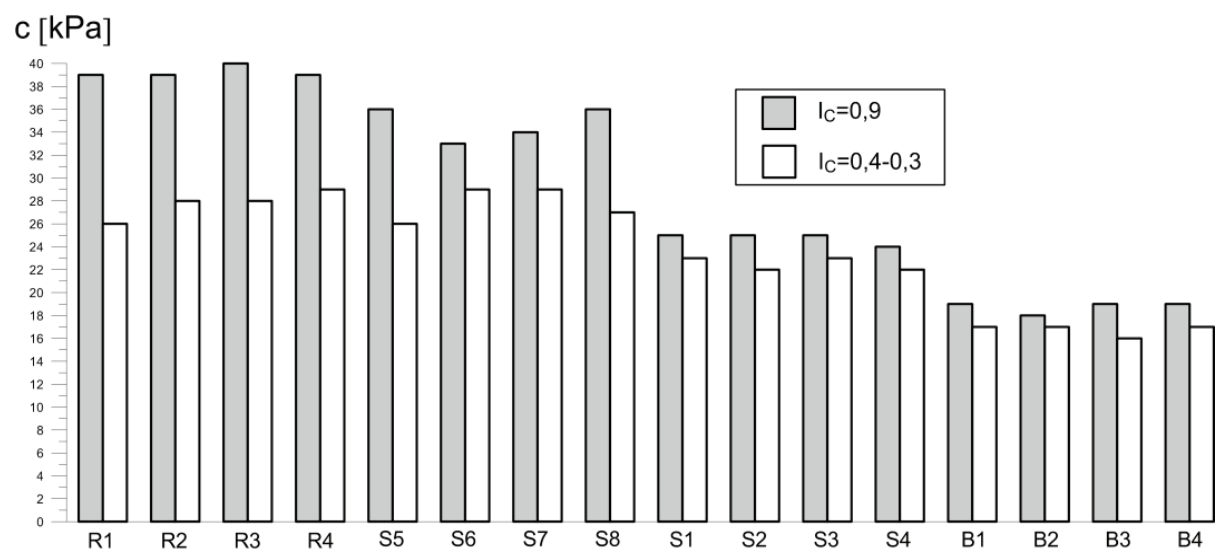

Fig. 8. Comparison of the cohesion for consistency index $I_{C}=0.9$ and $I_{C}=0.4-0.3$

consistency index of 0.9 in comparison to the consistency index value of $0.4-0.3$ reached $10-13 \mathrm{kPa}$. In the clay from Sulmierzyce, containing between $44.2 \%$ and $47.6 \%$ of the clay fraction, cohesion decreased by
4-10 $\mathrm{kPa}$ as a result of the moisture content increase, and in the clays with the clay fraction content of 37.1 $-37.9 \%$, by $1-2 \mathrm{kPa}$. In the clays with sand and silt from Biadki, containing nearly $28 \%$ of the clay frac- 
tion, the moisture content increase resulted in the decrease in the cohesion value by $1-3 \mathrm{kPa}$ (Fig. 8).

Upon test completion, the soil moisture was decreasing according to expectations. After shearing of stiff soils, the moisture content decreased by several per cent. Greater changes, which reached nearly 10 per cent, were determined in the soils of soft consistency.

The clays containing more clay fraction have different values of the shearing resistance when compared to the clays with sand and silt characterized by a lower amount of this fraction.

The greater angles of shearing resistance determined in the clays with sand and silt from Biadki (in comparison with the clays) result from a slightly bigger concentration of the sand fraction and the presence of a several percent amount of the gravel fraction. The increasing moisture content reduces the friction resistance leading to the decrease in the angle of shearing resistance.

A greater content of the clay fraction in the soil causes an increase in the number of contact points between particles per unit of the shearing plane. In the soils characterized by the lower moisture content, which contain chiefly strongly bonded water, the intensity of the mutual interactions between particles increases, resulting in the higher cohesion. The moisture content increase results in the increased distance between particles, reduced electrostatic and molecular interactions, and therefore in the lower cohesion. Therefore, in the soils containing more clay fraction, differences in the cohesion values among soils in the stiff and soft consistency are the greatest. It should be borne in mind, however, that the decrease in cohesion will not depend solely on the clay fraction content. The particle interaction intensity is controlled also by the width of the double electrical layer, which, in turn, depends on the chemical composition of water, the concentration of electrolytes and the cation valence.

In the shearing resistance tests, the cohesion and the angle of shearing resistance increase with the growing concentration of the clay fraction in the soil (Tiwari, Ajmera [28]). The greater content of coarser fractions results in a decrease in cohesion and an increase in the angle of shearing resistance, which is indicated in the papers by, e.g., Trask [30], Pakbaz, Moqaddam [17] and Yanrong [34].

Oedometric moduli of primary compressibility were calculated for the load ranges $0-100 \mathrm{kPa}$ and $100-200 \mathrm{kPa}$ and oedometric moduli of the secondary compressibility - for the ranges $12.5-100 \mathrm{kPa}$ and $100-200 \mathrm{kPa}$. The tests were also made in two series for the tills (clay with sand and silt) and the clays in the stiff $\left(I_{C}=0.9\right)$ and the soft consistency $\left(I_{C}=\right.$ $0.4-0.3$ ) (Table 3).

The test results imply that the moisture content increase caused a decrease in the values of the oedometric modulus of primary and secondary compressibility (Figs. 9 and 10). The lowest compressibility value for both load ranges was determined for soils with the clay fraction content above $40 \%$. The other soils showed considerable compressibility under these

Table. 3. The test results for oedometric modulus of primary $\left(M_{0}\right)$ and secondary $(M)$ compressibility for consistency index $I_{C}=0.9$ and $I_{C}=0.4-0.3$

\begin{tabular}{|c|c|c|c|c|c|c|c|c|c|c|c|c|c|}
\hline \multirow{2}{*}{ No. } & \multirow{2}{*}{ 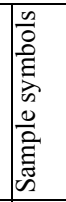 } & \multirow{2}{*}{$\begin{array}{c}\text { Moisture } \\
w_{n}[\%]\end{array}$} & \multirow{2}{*}{$\begin{array}{c}\text { Consistency } \\
\text { index } I_{C}\end{array}$} & $\begin{array}{c}\text { Primary } \\
\text { modulus } \\
M_{0}[\mathrm{kPa}] \\
\end{array}$ & $\begin{array}{c}\text { Primary } \\
\text { modulus } \\
M_{0}[\mathrm{kPa}]\end{array}$ & $\begin{array}{l}\text { Secondary } \\
\text { modulus } \\
M[\mathrm{kPa}]\end{array}$ & $\begin{array}{l}\text { Secondary } \\
\text { modulus } \\
M[\mathrm{kPa}]\end{array}$ & \multirow{2}{*}{$\begin{array}{c}w^{\prime} \\
{[\%]}\end{array}$} & \multirow[t]{2}{*}{$I_{C}^{\prime}$} & \begin{tabular}{|c|} 
Primary \\
modulus \\
$M_{0}[\mathrm{kPa}]$
\end{tabular} & $\begin{array}{c}\text { Primary } \\
\text { modulus } \\
M_{0}[\mathrm{kPa}]\end{array}$ & $\begin{array}{l}\text { Secondary } \\
\text { modulus } \\
M[\mathrm{kPa}]\end{array}$ & $\begin{array}{c}\text { Secondary } \\
\text { modulus } \\
M[\mathrm{kPa}]\end{array}$ \\
\hline & & & & $\begin{array}{l}0-100 \\
{[\mathrm{kPa}]}\end{array}$ & $\begin{array}{c}100-200 \\
{[\mathrm{kPa}]}\end{array}$ & $\begin{array}{c}12.5-100 \\
{[\mathrm{kPa}]}\end{array}$ & $\begin{array}{c}100-200 \\
{[\mathrm{kPa}]}\end{array}$ & & & $\begin{array}{l}0-100 \\
{[\mathrm{kPa}]}\end{array}$ & $\begin{array}{c}100-200 \\
{[\mathrm{kPa}]}\end{array}$ & $\begin{array}{c}12.5-100 \\
{[\mathrm{kPa}]}\end{array}$ & $\begin{array}{c}100-200 \\
{[\mathrm{kPa}]}\end{array}$ \\
\hline 1 & R1 & 22.8 & 0.9 & 8300 & 11000 & 117500 & 32700 & 57.3 & 0.3 & 5000 & 6500 & 42400 & 27700 \\
\hline 2 & R2 & 23.2 & 0.9 & 11100 & 16500 & 172700 & 65800 & 62.7 & 0.3 & 6100 & 7600 & 42700 & 27800 \\
\hline 3 & R3 & 22.7 & 0. & 7600 & 8900 & 124200 & 33600 & 61.5 & \begin{tabular}{|l|}
0.3 \\
\end{tabular} & 4700 & 6200 & 43700 & 19900 \\
\hline 4 & R4 & 23 & 0.9 & 12400 & 16200 & 121000 & 57000 & 52.7 & 0.4 & 5300 & 500 & 300 & 29700 \\
\hline 5 & S5 & 23.8 & 0.9 & 8000 & 9900 & 61500 & 49000 & 47.2 & 0.4 & 6100 & 6800 & 42300 & 24300 \\
\hline 6 & S6 & & 0.9 & 10000 & 14100 & 65300 & 55100 & 51.3 & 0.4 & 5900 & 7400 & 100 & 24300 \\
\hline 7 & S7 & 22.2 & 0.9 & 9400 & 11000 & 51600 & 44700 & 50.1 & \begin{tabular}{|l|}
0.4 \\
\end{tabular} & 6200 & 7100 & 39500 & 30600 \\
\hline 8 & S8 & 23 & 0.9 & 9500 & 12500 & 48600 & 43100 & 47.9 & \begin{tabular}{|l|} 
\\
\end{tabular} & 6200 & 6800 & 41200 & 39700 \\
\hline 9 & S1 & 15.6 & 0.9 & 3900 & 6100 & 42100 & 32000 & 40 & 0.3 & 2400 & 4000 & 32900 & 20800 \\
\hline 10 & S2 & 15.6 & 0.9 & 3900 & 6900 & 33700 & 27400 & 41.1 & \begin{tabular}{|l|}
0.3 \\
\end{tabular} & 2400 & 3800 & 29500 & 14400 \\
\hline 11 & S3 & 15.4 & 0.9 & 3800 & 7200 & 37800 & 33400 & 37.5 & 0.3 & 2600 & 3900 & 29700 & 20500 \\
\hline 12 & S4 & 16 & 0.9 & 4200 & 6700 & 35200 & 30900 & 38.2 & \begin{tabular}{|l|}
0.4 \\
\end{tabular} & 2800 & 4300 & 27400 & 24700 \\
\hline 13 & B1 & 12.5 & 0.9 & 4000 & 5700 & 28400 & 17600 & 30.4 & 0.3 & 2500 & 3400 & 18600 & 13600 \\
\hline 14 & B2 & 13.1 & 0.9 & 3100 & 5300 & 29900 & 13000 & 27.5 & \begin{tabular}{|l|}
0.3 \\
\end{tabular} & 2600 & 3300 & 20900 & 11900 \\
\hline 15 & B3 & 12.8 & 0.9 & 4000 & 5600 & 26700 & 15400 & 24.4 & 0.4 & 2500 & 3500 & 18500 & 12500 \\
\hline 16 & B4 & 12.9 & 0.9 & 4500 & 5500 & 28200 & 13400 & 26.5 & 0.4 & 3000 & 3700 & 23600 & 9800 \\
\hline
\end{tabular}




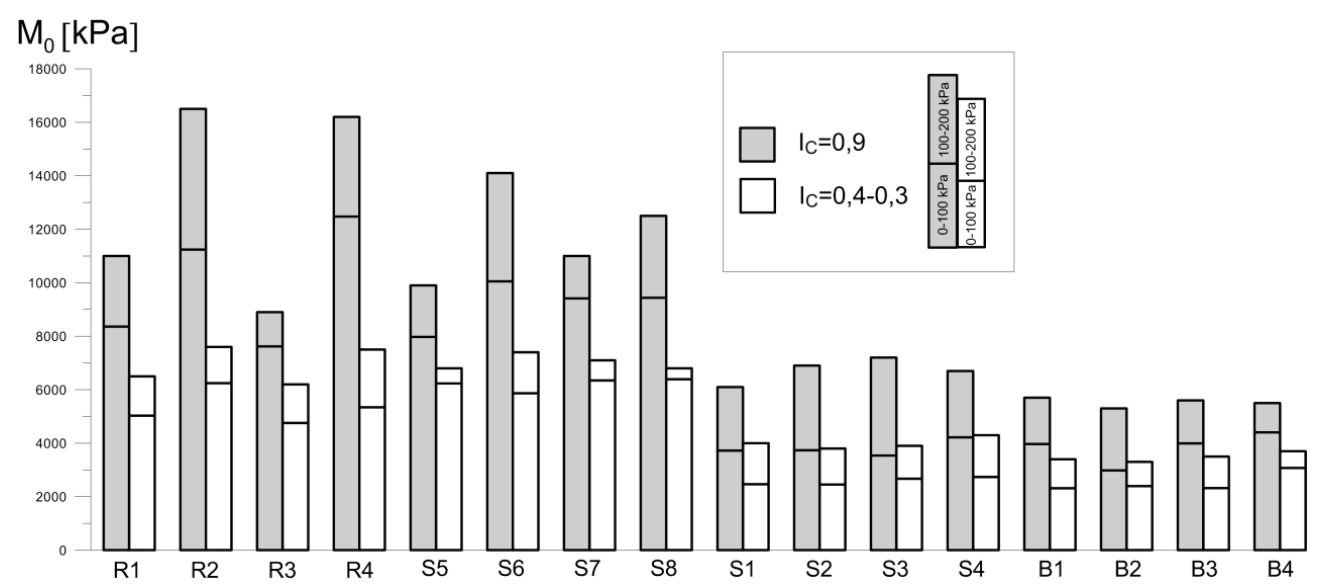

Fig. 9. Comparison of the oedometric modulus of primary compressibility for consistency index $I_{C}=0.9$ and $I_{C}=0.4-0.3$

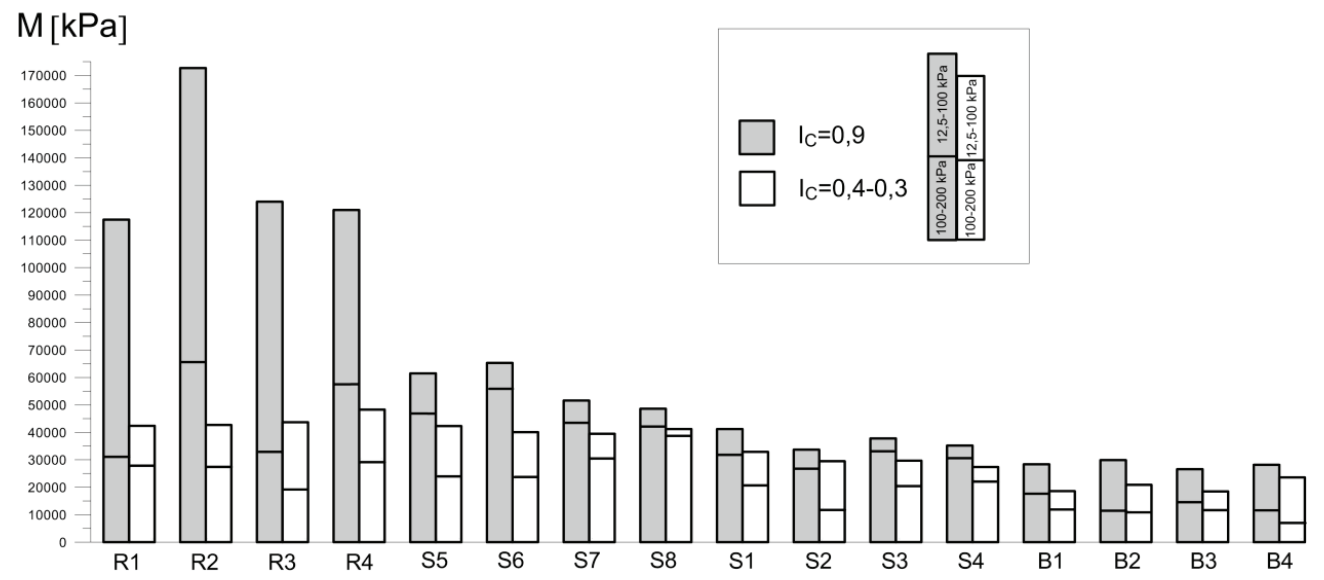

Fig. 10. Comparison of the oedometric modulus of secodary compressibility for consistency index $I_{C}=0.9$ and $I_{C}=0.4-0.3$

conditions. The high oedometric modulus of secondary compressibility (especially in the load range $12.5-100 \mathrm{kPa}$ ) should also be stressed. This is indicative of a possible decrease in the soil compressibility as a result of the preliminary loading, i.e., the improvement of the soil strength.

Upon completing compressibility test, a considerable decrease in the moisture content was observed in the soil pastes, both in the soils of the stiff and the soft consistency (Table 3). The loss of water up to over $50 \%$ in all the samples was tested.

The compressibility increased strongly in soils characterized by the soft consistency, which is supported by the results obtained by other authors (Wdowska [33]). A particularly high compressibility is typical of the clay and till (clay with sand and silt) with the clay fraction content below $40 \%$. In the soils containing the clay fraction, the water permeability decreases - these are impermeable or poorly permeable soils characterized by difficult water percolation. This is also a long-term process. Water is connected to the particle surface, which entails significant stress that increases the soil resistance to the load applied (Szymański [26]). The increase in the water saturation of spaces between the particles and pores in the soil, results in an increased distance and a reduced stress between them. As a result, the soil resistance to the load decreases and its compressibility increases (Alikonis [1], Szymański [26]). The values of the oedometric modulus of compressibility in the soft consistency classify the soils as weak due to their significant compressibility (Singh et al. [24], Dave et al. [7], Olsson et al. [16] and Mamat [13]).

\section{CONCLUSION}

The paper presents results of investigations of the angle of shearing resistance, cohesion and compressibility obtained for the Poznan clays and glacial tills from Rawicz and Krotoszyn vicinity. The investigations were conducted on soil pastes in the stiff consistency $\left(I_{C}=0.9\right)$ and the soft consistency $\left(I_{C}=\right.$ 
0.4-0.3). Those soils were the basis for the determination of variations of the aforementioned parameters depending on the soil consistency that, in turn, depends on the moisture content. According to the predictions, the increasing moisture content caused the reduction of these parameter values, i.e., resulting in the decrease in the soil properties in terms of usefulness as a building subbase.

Due to the fact that the investigations were performed on soil pastes with the volumetric density reflecting the in-situ values, the results may (with a certain approximation) be referred to soils that form the building substrate. Where such soils are used to construct the waste landfill lining or hydro-engineering structures need to be compacted. It is a well-known fact that the maximal compaction is obtained at the optimum moisture content. The results imply the importance of the selection of adequate compaction conditions, for which the moisture content increase will not diminish the shearing resistance and compressibility. On the basis of the investigation results it is possible to state that the moisture content increase has a greater negative impact on the soil compressibility than on the shearing resistance.

The values of the angle of shearing resistance and cohesion in the soft soils decreased to a lesser extent than the oedometric modulus of compressibility that showed a considerable reduction in the case of soils in this consistency. A particularly high compressibility is typical of the soils with the clay fraction content in the range of $28-38 \%$. It was also observed that regardless of the soil consistency the angle of shearing resistance decreases and the cohesion and the oedometric modulus of primary and secondary compressibility grows with the increase in the clayey fraction.

\section{ACKNOWLEDGEMENTS}

Investigations were conducted in Engineering Geology Laboratory of the Institute of Geological Sciences at Wrocław University.

\section{REFERENCES}

[1] Alikonis A., The influence of natural humidity upon the index of the compression of limnoglacial clay, Civil Engineering, Wilno, 2001.

[2] BŁaszczyK J., Szczegółowa Mapa Geologiczna Polski - Arkusz Krotoszyn - 619, Wyd. PIG, Warszawa, 1993.

[3] BorowczAK P., O wtaściwościach gruntów mało spoistych zmieniajacych się w procesie konsolidacji, Geologia, Kraków, 2008.

[4] Based on investigation of soil paste.
[5] Choma-Moryl K., Chemiczno-fizyczne własności iłów poznańskich Polski południowo-zachodniej na przykładzie wybranych odstonięć, Prace Mineralogiczne, Wyd. Uniwersytetu Wrocławskiego, Wrocław, 1992, Vol. XXVI.

[6] Chudy K., PaWlaK K., Parametry wytrzymałościowe gruntów spoistych z rejonu Ostrowa Wielkopolskiego zaburzonych glacitektonicznie - nowe możliwości i problemy interpretacyjne, KGHM CUPRUM, Wrocław, 2013.

[7] Dave C., Law K., Soft Soil Engineering. Proceedings of the Fourth International Conference on Soft Soil Engineering, Vancouver, 2006.

[8] DoBAK P., KowalczyK S., Zachowania konsolidacyjne past gruntowych jako potencjalnego materiatu izolacyjnego, Przegląd Geologiczny, 2010.

[9] DuCZMAL-CZERNIKIEWICZ A., Struktury iłów poznańskich $w$ obserwacjach makroskopowych jako wskaźniki poligenezy osadów, Wyd. PIG, Warszawa, 2011.

[10] Gan J., Rahardio D., Determination of the shear strenght parameters of an unsaturated soil using the direct shear test, Canadian Geotechnical Journal, Saskatoon, 1988.

[11] Kajetańczyk R., Konieczna R., Stawska E., SKOLIMOWSKA E., WLEKLIŃSKA J., WOŹNIAK J., ZAGDAŃSKA E., Studium uwarunkowań i kierunków zagospodarowania przestrzennego dla miasta i gminy Krotoszyn, Integra, Krotoszyn, 2013.

[12] Kasiński J., Czapowski G., Profil utworów formacji poznańskiej w środkowej części Niżu Polskiego, Wyd. Prz. Geol. 56, Warszawa, 2002, 256.

[13] Mамат C., Engineering properties of Batu Pahat soft clay stabilized with lime, cement and bentonite for subgrade in road construction, Universiti Tun Hussein, Malezja, 2012.

[14] MYŚLIŃSKA E., Laboratoryjne badania gruntów i gleb, Wyd. Uniwersytetu Warszawskiego, Warszawa, 2010.

[15] NowaK J., Szczegółowa Mapa Geologiczna Polski - Arkusz Rawicz - 654, Wyd. PIG, Warszawa, 1992.

[16] Olsson M., Alen C., Karstunen M., Modelling compressibility of soft soils with anisotropic material models, Chalmers University of Technology, Gothenburg, 2012.

[17] Pakbaz M., MoQAdDam A., Effect of Sand Gradation on The Behavior of Sand-Clay Mixtures, University of Shahid, Iran, 2012

[18] PISARCZYK S., Badanie wytrzymałości na ścinanie gruntów spoistych $w$ zależności od wilgotności i konsolidacji, Politechnika Warszawska, Warszawa, 2009.

[19] PIWOCKI M., Ewolucja pogladów na stratygrafie utworów formacji poznańskiej na Niżu Polskim, Wyd. Prz. Geol., Warszawa, 2002, 56, 255.

[20] PKN-CEN ISO/TS 17892-5:2009: Badania geotechniczne - Badania laboratoryjne gruntów - Część 5: Badanie edometryczne gruntów.

[21] PN-EN ISO 14688-1:2006: Badania geotechniczne - Oznaczanie i klasyfikowanie gruntów - Część 1: Oznaczanie i opis.

[22] PN-EN ISO 14688-2:2006: Badania geotechniczne - Oznaczanie i klasyfikowanie gruntów - Część 2: Zasady klasyfikowania.

[23] PN-EN 1997-2:2009: Eurokod 7 - Projektowanie geotechniczne-Część 2: Rozpoznanie i badanie podłoża gruntowego.

[24] Singh A., Kishore N., Gupta S., Kumar A., Kumar S., Guidelines on soft soils - stage construction method, Government of India, Ministry of Railwayws, India, 2005.

[25] SzCZEPAŃSKi T., Przyktady zastosowań koncepcji parametrów inherentnych $w$ badaniach gruntów spoistych, Geologos, Poznań, 2007. 
[26] SZYMAŃSKi A., Mechanika gruntów, SGGW, Warszawa, 2007.

[27] Szymkowiak I., Witkowska J., PRZYbyŁa M., Sergiel E., KRYSIAK Ż., Aktualizacja programu ochrony środowiska dla gminy rawicz na lata 2008-2011 z perspektywa na lata 2012-2014, Biuro Projektowe Abrys, Poznań, 2008.

[28] Tiwari B., AJMera B., A new correlation relating the shear strength of reconstituted soil to the proportions of clay minerals and plasticity characteristics, Applied Clay Science, Fullerton, 2011.

[29] Consolidation and Permeability of Clay Minerals - Expansive to Non-expansive, Geo-Frontiers, Dallas, 2011.

[30] TRASK P., Effect of grain size on strenght of mixtures of clay, sand, and water, Department of Engineering, Berkeley, 1959.

[31] Urząd Miasta Krotoszyn, Plan Rozwoju Lokalnego Miasta $i$ Gminy Krotoszyn na lata 2004-2007, Krotoszyn, 2006.
[32] Valasti P., Improved Soil Stabilization by Geoelectrical Water Content Determination and Statistical Shear Strength Models, Journal of Environmental \& Engineering Geophysics, 2010.

[33] WDOWSKA M., Wpływ zmian stopnia wilgotności na charakterystyki ściśliwości w badaniach edometrycznych, Architectura, Warszawa, 2013.

[34] YANRONG L., Effects of particle shape and size distribution on the shear strength behavior of composite soils, Bulletin of Engineering Geology and the Environment, Berlin, 2013.

[35] Yuan J., Fang Y., Gu R., Hu G., Peng X., Experimental Research on Influence of Granulometric Composition on Sandy soil Strength and Rheological Properties, Guangdong, 2013. 